\title{
The response of river nitrification to changes in wastewater treatment (The case of the lower Seine River downstream from Paris)
}

\author{
Najla Aissa-Grouz ${ }^{1 *}$, Josette Garnier ${ }^{1,2}$, Gilles Billen ${ }^{1,2}$, Benjamin Mercier ${ }^{1}$ and \\ Anunciacion Martinez ${ }^{1}$ \\ 1 University of Pierre and Marie Curie, UMR 7619 Metis, box 105, 4 place Jussieu, 75252 Paris Cedex 05, France \\ 2 National Center of Scientific Research, UMR 7619 Metis, box 105, 4 place Jussieu, 75252 Paris Cedex 05, France
}

Received 24 March 2015; Accepted 28 September 2015

\begin{abstract}
In the early 2000s, most of the effluents from the Paris agglomeration (12 million inhabitants) were still discharged after only a standard activated sludge treatment of carbon, thus releasing a high ammonium load. This triggered the growth of nitrifying bacteria in the river and caused a deficit of dissolved oxygen concentration $200 \mathrm{~km}$ downstream, at the entrance of the estuarine area. From 2007 on, improvements of the wastewater treatment plant (WWTP) helped to nitrify most of the ammonium, and to denitrify $70 \%$ of the nitrate produced since 2012. This paper documents the effect of these recent changes in the treatment of Paris effluents, based on measurements of nitrogen species concentrations and nitrifying activities along longitudinal profiles of the lower Seine River. These observations are put into perspective with respect to previous observations, and a modeling approach is developed to evidence the role of ammonium and nitrifying organisms released with the WWTP effluents into the receiving water body. Today, a larger biomass of ammoniumoxidizing microbes is being discharged by the WWTP, but the microorganisms released do not grow, possibly because of the low substrate in the river. The same is true for nitrite-oxidizing microbes, which explains the persistence of nitrite often discharged with the effluents because of incomplete nitrification and/or denitrification in the treatment line. Taking into account the development of microbial populations of nitrifying organisms is essential to explain the observed spatial and temporal pattern of the nitrogen species.
\end{abstract}

Key words: Nitrification / nitrifying potential activities / nitrogen contamination / domestic effluents / water quality

\section{Introduction}

Nitrification plays a major role in rivers and estuaries, not only as a key step in the nitrogen cycle, converting ammonium to nitrite and nitrate with $\mathrm{N}_{2} \mathrm{O}$ emissions (Somville et al., 1982; de Wilde and de Bie, 2000; Garnier et al., 2006a), but also in the oxygen balance: in water bodies receiving urban effluents, nitrification can be responsible for a significant and sometimes dominant proportion of their oxygen depletion, as was the case, for example, in the lower Rhine River in the late 1980s (Müller and Kirchesch, 1985; Admiraal and Botermans, 1989) and in the Pearl River estuary (He et al., 2014). In small, shallow rivers nitrification is mainly a benthic process (Curtis et al., 1975; Cooper, 1984; Pauer and Auer, 2000):

\footnotetext{
*Corresponding author: najla.grouz-jerbi@upmc. fr
}

very few nitrifying organisms are present in the water column because of their low growth rate and their propensity to attach to particles and to settle with them (Prosser, 1989; Brion et al., 2000). In turbid estuaries, by contrast, tidal mechanisms concentrate particles in a defined sector of the estuary where suspended solids experience a longer residence time than the water masses themselves, offering the attached nitrifying organisms the opportunity to develop a high biomass (Xia et al., 2004). The maximum turbidity zone of macrotidal estuaries is therefore a spot of high potential nitrification (Billen, 1975; Helder and De Vries, 1983; de Wilde and de Bie, 2000; Garnier et al., 2001; de Bie et al., 2002). Owens (1986) even compared estuarine nitrification to a naturally occurring fluidized bed reaction.

The case of large rivers is intermediate. Given that the low ratio of sediment surface with respect to water column 
volume seriously reduces the significance of benthic processes, the potential for nitrification in rivers depends on the capacity of nitrifying bacteria to maintain and develop significant populations in the water column. By comparing nitrification rates in three branches of the lower river Rhine, Admiraal and Botermans (1989) concluded that factors leading to resuspension of sediments, such as a high flow rate or turbulence linked to shipping, are major determinants of the intensity of nitrification. Indeed, rivers with high turbidity such as the Yellow River have high nitrification potential (Xia et al., 2004). Another major factor controlling nitrification in rivers is the inoculation of nitrifying bacteria along with urban wastewater, often supplying the receiving river stretch both with the substrate (ammonium) and the organisms able to metabolize it (Brion et al., 2000).

The application of both national and European directives (e.g., EU-Urban waste water treatment directive, UWWTD, 1991; EU-Water framework directive, WFD, 2000) incited water managers to improve wastewater treatment. Mainly targeting urban point sources, this policy led to massive decreases of carbon, ammonium and phosphorus emissions to rivers and considerably improved surface waters quality (Bouraoui and Grizzetti, 2011; Garnier et al., 2013; Passy et al., 2013).

The particularly well-studied lower Seine, receiving the effluents from the Paris agglomeration (12 million inhabitant equivalents), represents an interesting case study because the changes in the in-stream nitrification processes related to the gradual improvement of wastewater purification can be followed.

Until the late 1990s, the removal of organic loading was the main objective of water-quality managers. In the 1970s, a significant fraction of Paris wastewater was still discharged without treatment, causing a major drop in oxygen concentration in a $100 \mathrm{~km}$ river stretch immediately downstream the largest wastewater treatment plant (WWTP) of Paris conurbation, called Seine Aval (SAV) at $65 \mathrm{~km}$ (Chesterikoff et al., 1992). Better organic matter elimination from sewage improved the oxygenation level in this sector. However, in the early 2000 s most of the effluents were still discharged after only a standard, low residence time, activated sludge treatment of organic matter, thus releasing a high ammonium load. Cébron et al. (2003, 2005) and Garnier et al. (2007) described how these massive ammonium concentrations triggered the growth of nitrifying bacteria in the river, which resulted in a serious deoxygenation of the water column, $200 \mathrm{~km}$ downstream, at the entrance of the estuarine area. Moreover, using denaturing gradient electrophoretic analysis of the DNA from the ammonia-oxidizing bacterial community in the lower Seine River, Cébron et al. (2004) showed the subsequent growth of the ammoniaoxidizing Nitrosomonas strains coming from the effluents in the ammonium-enriched river water. Similar results were obtained with the nitrite-oxidizing bacterial community (Cébron and Garnier, 2005), Nitrospira dominating downstream along the river, whereas both Nitrobacter and Nitrospira were brought by the effluents.
Recently considerable advances made to wastewater treatment in the Paris region have profoundly changed the biogeochemical functioning and water quality of the main branch of the Seine River. From 2007 on, all ammonium from wastewater was nitrified, and $30 \%$ of the nitrate formed was denitrified. Since 2012, the SAV WWTP has achieved its full transformation with complete nitrification (up to $95 \%$ of the ammonium treated by nitrification) and denitrification of all effluents (elimination of $70 \%$ of the nitrate produced) (V. Rocher, personal communication, 2014). The objective of the present paper is to document the changes in the dynamics of nitrogen and nitrifying microbial communities in the lower Seine River, in view of the new treatments of Paris effluents. We analyze the effect of these most recent changes with respect to previous observations. Attention is paid to the dynamics of nitrite, an intermediate in the two steps of nitrification, which is above standard values in the effluent-impacted sectors of the river (EU-WFD, 2000). We also developed a modified modeling approach (Cébron et al., 2005; Garnier et al., 2007) to represent the dynamics of ammonium- and nitrite-oxidizing microbial populations before and after the implementation of nitrification treatment of Paris wastewater.

\section{Materials and methods}

\section{Study site and long-term water-quality data}

The study site (Fig. 1) embraces the Seine River from the confluence of the Marne River, just upstream of Paris $(0 \mathrm{~km})$, to the lower part of the Seine estuary at Tancarville, $337 \mathrm{~km}$ downstream. Poses, at $202 \mathrm{~km}$, marks the limit between the lower Seine River and its estuary, with tidal movement stopped by a navigation weir. The SAV wastewater purification plant at Achères, at $65 \mathrm{~km}$, is one of the largest in Europe and treats the domestic effluents of up to 6 million inhabitant equivalents of the Paris conurbation. Table 1 provides a summary of the improvements made to its performance over the last 40 years.

The water-quality database from the RNB (Réseau National de Bassins) initiated by the Agence de l'Eau Seine Normandie (AESN), together with the results of our own measurements, were used to characterize the changes of water quality at the stations upstream and downstream of the SAV plant over the period from 1993 to 2013 . We selected the values corresponding to summer situations of low flow ( $<200 \mathrm{~m}^{3} . \mathrm{s}^{-1}$ at Paris intra muros), and nitrogen fluxes (ammonium $\mathrm{NH}_{4}^{+}$, nitrite $\mathrm{NO}_{2}^{-}$, nitrate $\mathrm{NO}_{3}^{-}$) were calculated by multiplying the concentrations with the corresponding discharge values, taking into account the discharge of wastewater effluents by the WWTP itself.

\section{Sampling strategy}

Eight sampling campaigns were organized to analyze the longitudinal distribution of inorganic nitrogen forms. 


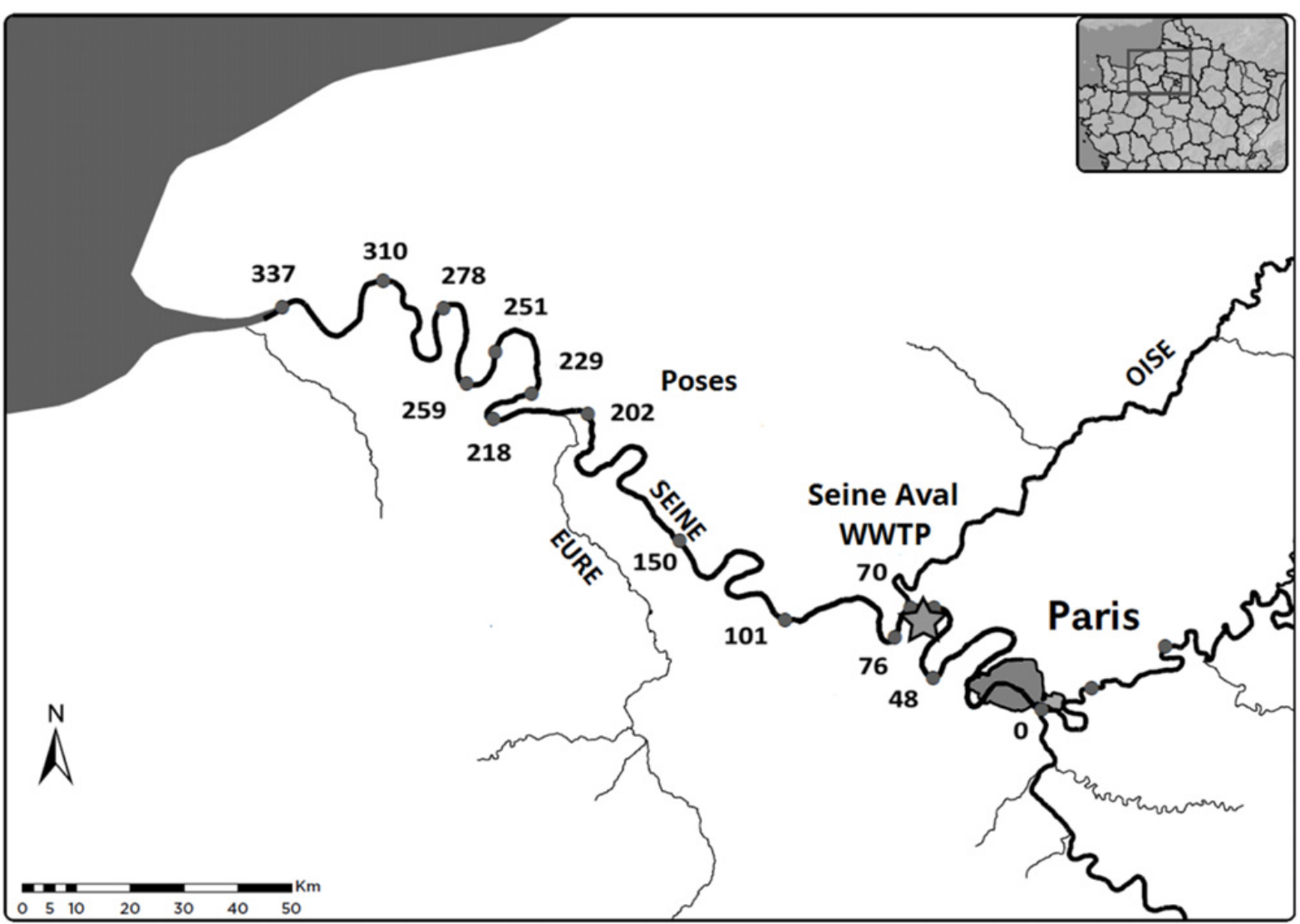

Fig. 1. Sampling stations in the major branch of the lower Seine River from Paris to Tancarville $(0-337 \mathrm{~km})$.

Table 1. Improvement in the performance of the SAV treatment plant at Achères under dry weather conditions since 1970.

\begin{tabular}{|c|c|c|c|c|c|}
\hline & $\begin{array}{l}\text { Treatment capacity } \\
\left(\mathrm{mm}^{3} \cdot \text { day }^{-1}\right)\end{array}$ & $\begin{array}{l}\text { Inhab equiv } \\
\text { (million) }\end{array}$ & $\begin{array}{l}\text { Volume treated } \\
\left(\mathrm{m}^{3} \mathrm{~s}^{-1}\right)\end{array}$ & Treatment applied & Comments \\
\hline$\overline{1970}$ & 0.6 & 1.5 & 6.9 & $\begin{array}{l}\text { Conventional high loading } \\
\text { activated sludge process }\end{array}$ & Achères I + II \\
\hline 1972 & 1.5 & 3.75 & 18 & “ & Start Achères III \\
\hline 1978 & 2.1 & 5.25 & 25 & “ & Start Achères IV \\
\hline 1987 & 2.1 & 6 & 25 & “ & $\begin{array}{l}\text { Abstraction of a fraction } \\
\text { of the load to Seine } \\
\text { Amont plant }\end{array}$ \\
\hline 2000 & 2.1 & $5.9^{\mathrm{a}}$ & 23 & Phosphorus treatment & \\
\hline 2007 & 1.7 & $6.5^{\mathrm{b}}$ & 20 & Tertiary nitrification & \\
\hline 2012 & 1.7 & $5-5.5^{\mathrm{c}}$ & 17 & $\begin{array}{l}95 \% \text { nitrification and } 70 \% \\
\text { denitrification }\end{array}$ & \\
\hline
\end{tabular}

Sources: ${ }^{\text {a}}$ Tusseau-Vuillemin et al. (2002); ${ }^{\mathrm{b}}$ Garnier et al. (2008); ${ }^{\mathrm{c}}$ Vincent Rocher (personal communication).

During five of them (April, June and August 2012, September 2013 and May 2014), potential nitrifying activity was measured. All campaigns were carried out by relatively low flow periods; discharge could vary however from campaign to campaign between 200 and $100 \mathrm{~m}^{3} . \mathrm{s}^{-1}$, with obvious differences in nutrient concentrations. $\mathrm{NH}_{4}^{+}, \mathrm{NO}_{2}^{-}$, were less concentrated for flows close to $200 \mathrm{~m}^{3} \cdot \mathrm{s}^{-1}$ than during campaigns done during low flow $\left(\sim 100 \mathrm{~m}^{3} \cdot \mathrm{s}^{-1}\right)$.

Water samples were collected at 15 stations along the longitudinal profiles for nitrogen analysis. At each station,
20 L of water was collected with a bucket from bridges: a 10 - L container was stored until treatment and analysis in the laboratory within $24 \mathrm{~h}$ and the other $10 \mathrm{~L}$ was immediately used for field measurements (temperature, $\mathrm{pH}$, oxygen and conductivity).

Representative samples of treated water from the SAV WWTP were also collected in a refrigerated sampler over a 24-h cycle, with the assistance of the Syndicat Interdépartemental de l'Assainissement de l'Agglomération Parisienne (SIAAP) at the outflow effluent pipes. 


\section{Chemical analysis}

The water was filtered in the field or in the laboratory 4-5 h after sampling through a glass fiber membrane filter GF/F (Whatman) with $0.7-\mu \mathrm{m}$ porosity. The filtrate was frozen to analyze the inorganic nitrogen components. Ammonium, nitrite and nitrate concentrations were determined using an automatic analyzer (Quaatro, Bran $\&$ Luebbe) based on colorimetric techniques. The indophenol blue method was used to measure the ammonium concentration according to (Slawyk and MacIssac, 1972). Nitrate was determined after cadmium reduction to nitrite. Nitrite levels were automatically measured following the sulphanilamide colorimetric method (Jones, 1984).

\section{Measurement of nitrifying activities}

Potential nitrification activities were measured by following changes in nitrite concentration in samples enriched with ammonium and nitrite and treated with specific inhibitors of either ammonium or nitrite oxidation according to the method described by Cébron et al. (2003).

For each station, three series of samples were prepared in triplicate for four incubation times. All samples were analyzed for nitrite concentrations after being enriched with $28 \mathrm{mg} \mathrm{N}-\mathrm{NH}_{4}^{+} . \mathrm{L}^{-1}$ of $\mathrm{NH}_{4} \mathrm{Cl}$ and $0.3 \mathrm{mg}$ $\mathrm{N}-\mathrm{NO}_{2}^{-} \cdot \mathrm{L}^{-1}$ of $\mathrm{KNO}_{2}$ (Brion and Billen, 1998), i.e., at least ten times the half-saturation constant values of ammonium- and nitrite-oxidizing microorganisms. To determine the ammonium and nitrite oxidation rates, triplicate tests (with substrates, no inhibitor) were prepared and two other sets of triplicate separate samples were inhibited for all stations. One set of triplicate samples for determining the rate of ammonium oxidation was treated with allylthiourea $\left(10 \mathrm{mg} . \mathrm{L}^{-1}\right)$. The other set of samples dedicated to the measurement of the potential of nitrite oxidation was treated with sodium chlorate $\left(\mathrm{NaClO}_{3}^{-} ; 10 \mathrm{mM}\right)$. Nitrite was analyzed after $0,3,7$ and $24 \mathrm{~h}$ of incubation. The increase in nitrite concentrations generally remained linear during the whole incubation period. Microbial activities were blocked by adding mercuric chloride to the triplicate samples $(0.06 \%$ of $\mathrm{HgCl}_{2}$ ), so as to postpone the analysis. During incubation, samples were wrapped in aluminum foil to maintain them in the dark and gently shaken at a lab temperature of $25 \pm 1{ }^{\circ} \mathrm{C}$.

The nitrite concentrations for each specific inhibitor were plotted in relation to incubation time, and the slope of their regression line calculated for the ammonium and nitrite oxidation rates. The slope values were kept only when the regression coefficient was significantly different from zero (i.e., $R>0.5$ for 12 pairs of data). The ammonium oxidation activity (AOA, $\mu \mathrm{gN} \mathrm{L}^{-1} \cdot \mathrm{h}^{-1}$ ) represents the difference between the slope of the control and the slope of the regression line for the samples inhibited with allylthiourea. For nitrite-oxidizing activity (NOA, $\mu \mathrm{gN} \mathrm{L}^{-1} \cdot \mathrm{h}^{-1}$ ), the difference between the slope of the linear regression of the samples inhibited with sodium

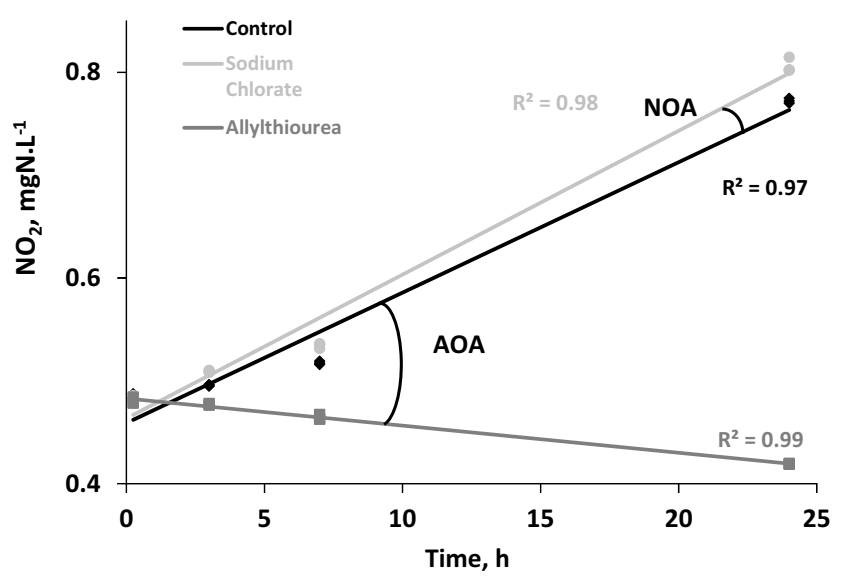

Fig. 2. Changes in nitrite concentrations within a control and the two inhibitors leading to the determination of the nitrification activities at Caudebec $310 \mathrm{~km}$ in September 2013. AOA: ammonium-oxidizing activity; NOA: nitrite-oxidizing activity.

chlorate and the slope of the control was calculated. An example of the results is provided in Figure 2.

To express these potential activity measurements in terms of biomass of the corresponding microorganism, we used the values proposed by Brion and Billen (1998) for the maximum specific activity of ammonium- and nitrite-oxidizing microorganisms, respectively 0.95 and $3 \mu \mathrm{gN} \cdot \mathrm{h}^{-1} \cdot \mu \mathrm{gC} \mathrm{C}^{-1}$ at $20^{\circ} \mathrm{C}$ :

$$
\begin{aligned}
& \text { Ammonium - oxidizing biomass }\left(\mu \mathrm{g} \mathrm{C} \mathrm{L}^{-1}\right) \\
& =\operatorname{AOA}\left(\mu \mathrm{g} \mathrm{N} \mathrm{L}^{-1} \cdot \mathrm{h}^{-1}\right) / 0.95\left(\mu \mathrm{g} \mathrm{N}^{-1} \cdot \mu \mathrm{g} \mathrm{C}^{-1}\right) \\
& \text { Nitrite }- \text { oxidizing biomass }\left(\mu \mathrm{g} \mathrm{C} \mathrm{L}^{-1}\right) \\
& \quad=\operatorname{NOA}\left(\mu \mathrm{g} \mathrm{N} \mathrm{L}^{-1} \cdot \mathrm{h}^{-1}\right) / 3\left(\mu \mathrm{g} \mathrm{N}^{-1} \cdot \mu \mathrm{g} \mathrm{C}^{-1}\right)
\end{aligned}
$$

\section{Results}

\section{Flux of nitrogen and microorganisms discharged by the SAV plant (1993-2014)}

Compared with the 2001-2002-2003 concentrations (Cébron et al., 2003; Cébron and Garnier, 2005), the analysis performed in 2012, 2013 and 2014 on treated water from the SAV WWTP sampled during several campaigns (Table 2) revealed lower $\mathrm{NH}_{4}^{+}$concentrations $\left(0.8-19\right.$ vs. $\left.22-46 \mathrm{mg} \mathrm{N}^{-1} \mathrm{~L}^{-1}\right)$, and higher $\mathrm{NO}_{2}^{-}(0.6-3.4$ vs. $0.07-0.28 \mathrm{mg} \mathrm{N} . \mathrm{L}^{-1}$ ) and $\mathrm{NO}_{3}^{-}$concentrations (4-37 vs. 2.4-3.5 mg N.L ${ }^{-1}$ ). This change is the obvious result of the implementation of nitrification/denitrification processes in the sewage treatment. Within the river, the median concentrations of ammonium at Conflans $(70 \mathrm{~km})$ was also lower for the recent period (0.6 vs. $4.2 \mathrm{mg} \mathrm{N} . \mathrm{L}^{-1}$ formerly), clearly showing the improvement of Parisian effluent treatment (Fig. 4) from 2007 onwards, despite occasional peaks observed during periods (Sept 2013, May 
Table 2. Estimates of the fluxes of ammonium and nitrifying biomass discharged in 2002-2003 (Cébron et al. 2004) and 2012-2014 (this study) by the SAV treatment plant estimated from direct measurements of nitrogen species and nitrifying biomass in treated wastewater effluents (the average discharging flow was $20 \mathrm{~m}^{3} \cdot \mathrm{s}^{-1}$ in 2002-2003 and $17 \mathrm{~m}^{3} . \mathrm{s}^{-1}$ in 2012-2014).

\begin{tabular}{|c|c|c|c|c|c|c|c|c|}
\hline & $\begin{array}{c}\mathrm{NH}_{4}^{+} \\
\mathrm{mg} \mathrm{N} \mathrm{L}^{-1}\end{array}$ & $\begin{array}{c}\mathrm{NO}_{2}^{-} \\
\mathrm{mg} \mathrm{N} \mathrm{L}^{-1}\end{array}$ & $\begin{array}{c}\mathrm{NO}_{3}^{-} \\
\mathrm{mg} \mathrm{N} \mathrm{L}^{-1}\end{array}$ & $\begin{array}{l}\text { Ammonium } \\
\text { flux } \\
\text { Tons N day }^{-1}\end{array}$ & $\begin{array}{c}\text { Oxidizing } \\
\text { ammonium } \\
\text { activity } \\
\mathrm{mg} \mathrm{N} \mathrm{L}^{-1} \mathrm{~h}^{-1}\end{array}$ & $\begin{array}{c}\text { Oxidizing } \\
\text { nitrite } \\
\text { activity } \\
\mathrm{mg} \mathrm{N} \mathrm{L}^{-1} \mathrm{~h}^{-1}\end{array}$ & $\begin{array}{l}\text { Ammonium- } \\
\text { oxidizing } \\
\text { biomass } \\
\text { fluxes } \\
\text { kg C day }^{-1}\end{array}$ & $\begin{array}{l}\text { Nitrite- } \\
\text { oxidizing bio- } \\
\text { mass fluxes } \\
\mathrm{kg} \mathrm{C} \mathrm{day}^{-1}\end{array}$ \\
\hline \multicolumn{9}{|c|}{ Prior $\mathrm{N}$ treatment $2002-2003$} \\
\hline May-02 & 29.9 & 0.09 & 2.7 & 51.67 & 6.7 & 0 & 12.2 & 0 \\
\hline July-02 & 21.5 & 0.24 & 3.12 & 37.5 & 143 & 2.8 & 26 & 1.6 \\
\hline Sept-02 & 33 & 0.3 & 3 & 57 & 18.6 & 3.5 & 33.8 & 2 \\
\hline April-03 & 45.7 & 0.24 & 2.4 & 97 & 3.2 & 4.2 & 5.8 & 2.4 \\
\hline May-03 & 43 & 0.07 & 2.8 & 74 & 2 & 3.4 & 3.6 & 2 \\
\hline Sept-03 & 33.6 & 0.2 & 3.5 & 58 & 51.5 & 5.6 & 93.7 & 3.2 \\
\hline Median & 33.6 & 0.22 & 2.9 & 57.54 & 10.5 & 3.5 & 19.1 & 2 \\
\hline SD & 9.6 & 0.09 & 0.38 & 15.2 & 18.5 & 1.85 & 33.7 & 1 \\
\hline \multicolumn{9}{|c|}{ With $\mathrm{N}$ treatment 2012-2014 } \\
\hline April-12 & 6.35 & 3.4 & 9.1 & 9.3 & 31.6 & 41.2 & 48.9 & 20.2 \\
\hline June-12 & 3.9 & 0.7 & 7.2 & 5.7 & 23.9 & 10.7 & 37 & 5.2 \\
\hline August-12 & 0.75 & 0.6 & 20 & 1.12 & 18.7 & 0.6 & 24.8 & 1.6 \\
\hline Median & 3.9 & 0.7 & 9.1 & 5.7 & 23.9 & 10.7 & 37 & 5.2 \\
\hline $\mathrm{SD}$ & 2.8 & 1.6 & 6.9 & 4.1 & 6.5 & 21.1 & 10 & 10.3 \\
\hline \multicolumn{9}{|c|}{ Maintenance situations } \\
\hline Sept-13 & 18.7 & 0.6 & 8.7 & 27.5 & 70.5 & 7 & 109 & 3.4 \\
\hline May-14 & 10.7 & 0.9 & 4 & 15.7 & 49.2 & 2.8 & 76 & 1.4 \\
\hline Median & 14.7 & 0.75 & 6.35 & 21.6 & 59.85 & 4.9 & 92.5 & 2.4 \\
\hline $\mathrm{SD}$ & 5.6 & 0.2 & 3.3 & 8.3 & 15 & 3 & 23.3 & 1.45 \\
\hline
\end{tabular}

2014) when the nitrification treatment line was shortcut for maintenance (see below).

Nitrogen fluxes from the SAV plant were calculated as the difference between the fluxes downstream of the SAV at the Conflans station $(70 \mathrm{~km})$ and those upstream at Maisons-Laffitte $(48 \mathrm{~km})$. Ammonium fluxes released by SAV were estimated at $71.1 \pm 28.1$ tons $\mathrm{N}_{\text {.day }}{ }^{-1}$ from 1993 to 2006 and reduced to $15.3 \pm 20.5$ tons N.day ${ }^{-1}$ from 2007 on (Fig. 4), except during the maintenance situations. Nitrite fluxes discharged have slightly increased from an average $1.2 \pm 1.9$ tons N.day ${ }^{-1}$ between 1993 and 2006, to $2.4 \pm 2.4$ tons N.day ${ }^{-1}$ between 2007 and 2013 . Similarly, nitrate fluxes, negligible before 2007, increased after 2007, reaching an average flux of $41.2 \pm 23.6$ tons N.day ${ }^{-1}$. Since 2012, the implementation of denitrification treatment clearly reduced the flux of discharged nitrate to $10.0 \pm 16.6$ tons N.day ${ }^{-1}$ (Fig. 4). These flux estimates obtained by the difference between upstream and downstream fluxes are consistent with those calculated as the product of the concentrations measured in the wastewater samples by the WWTP discharge (about $25 \mathrm{~m}^{3} . \mathrm{s}^{-1}$ in the $1990 \mathrm{~s}$ and $17 \mathrm{~m}^{3} . \mathrm{s}^{-1}$ after 2007) (Table 2). They are also in good agreement with the average daily fluxes reported by the managers of the SAV plant and summarized in Figure 4.

Through direct measurements of potential nitrifying activity in the WWTP effluents, we estimated the fluxes of nitrifying organisms discharged by the SAV WWTP (Table 2).
Values recorded for the 2002-2003 period by Cébron (2004, p. 131) for ammonium-oxidizing bacteria were in the $2-51.5 \mu \mathrm{g} \mathrm{N} . \mathrm{L}^{-1} \cdot \mathrm{h}^{-1}$ range and for the nitriteoxidizing bacteria in the $0-5.6 \mu \mathrm{g} \mathrm{N} . \mathrm{L}^{-1} \cdot \mathrm{h}^{-1}$ range. For the period after 2007, after implementation of a nitrification step in the treatment line, our measurements show values twice as high (Table 2).

\section{Longitudinal distribution in inorganic nitrogen and nitrifying activities by low flow (2002-2003 vs. 2011-2014)}

During the April-September period of 2012, 2013 and 2014 , low flows were generally observed in the lower part of the Seine River, varying from 81 to $242 \mathrm{~m}^{3} . \mathrm{s}^{-1}$ at Paris intra muros, similar to those observed in the 2002-2003 period. Water temperatures varied between 12 and $22^{\circ} \mathrm{C}$, $\mathrm{pH}$ between 6.8 and 8.6, and oxygen between 6.1 and $10.8 \mathrm{mg} \mathrm{O}_{2} . \mathrm{L}^{-1}$. The longitudinal distribution of oxygen and inorganic forms of nitrogen are compared with that observed during the 2002-2003 period by Cébron et al. (2003, 2004).

The improvement in Parisian wastewater treatment is clearly reflected by the distribution of inorganic nitrogen forms along the lower Seine River continuum by low summer flows. The first striking result concerns the areas of oxygen deficiency (Fig. 3). Two such areas occurred in 2002-2003, the first one immediately downstream of the 

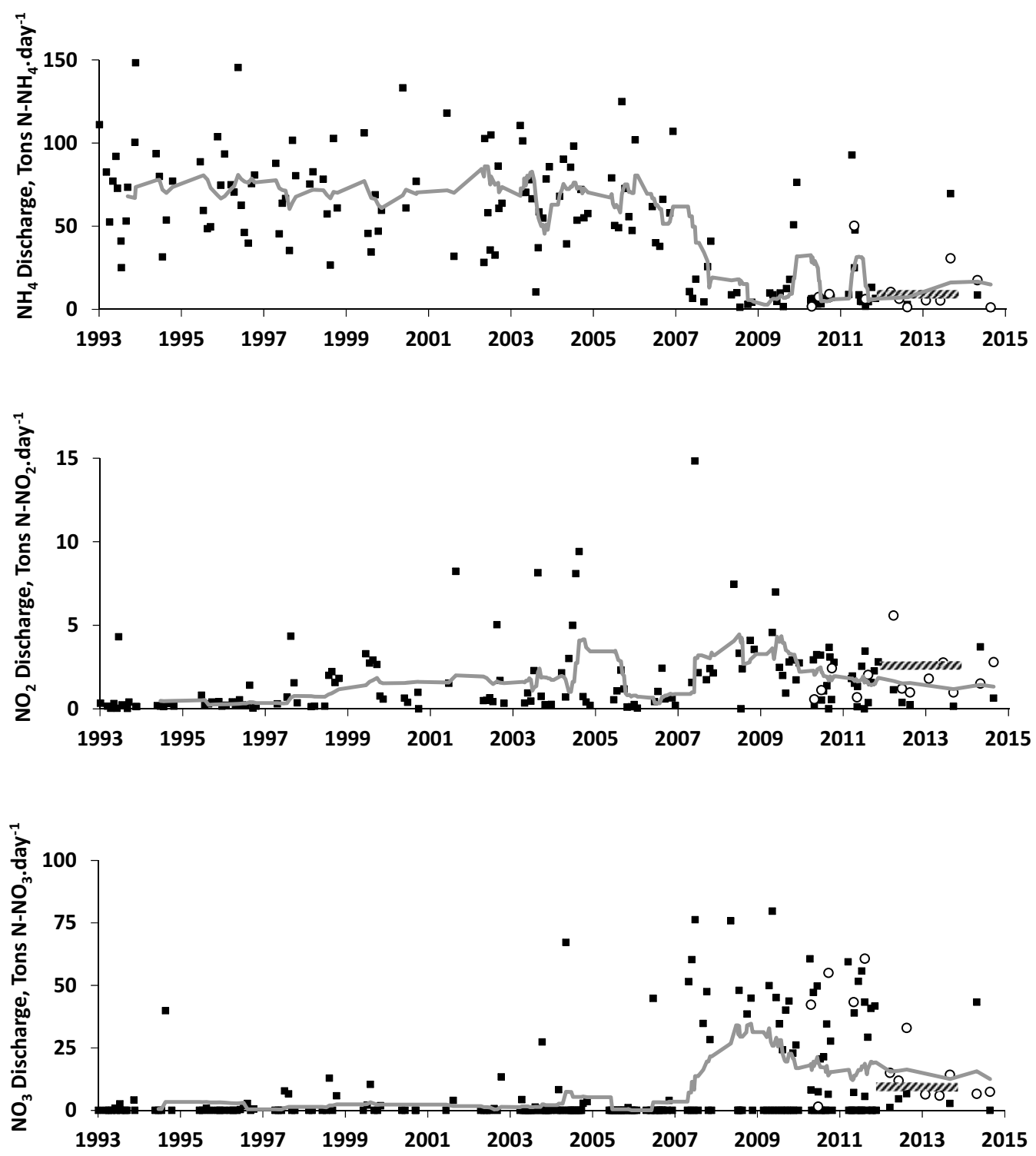

Fig. 3. Variations in ammonium, nitrite and nitrate fluxes discharged by the SAV treatment plant from 1993 to 2014 (calculated as the difference of fluxes between upstream and downstream stations, represented as squares). The solid line is the floating average (step, 14 months) through the data. Flux estimates from our own measurements on the effluents (circles), and average estimates provided by the managers of the SAV plant (hatched rectangles) are also shown for comparison.

WWTP related to organic matter degradation by heterotrophic bacteria and the second one in the estuarine zone, assigned to nitrification (Billen et al., 2001; Garnier et al., 2001). Both oxygen deficit areas completely disappeared in the 2012-2014 period and hypoxia no longer occurs.

The longitudinal profiles of ammonium concentration also reflect the changes in nitrogen treatment at the SAV plant (Fig. 3). In 2001-2003, ammonium concentrations reached $7 \mathrm{mg} \mathrm{N} . \mathrm{L}^{-1}$ downstream of the SAV and remained at high levels, until the beginning of the estuarine sector where they were totally oxidized, while they have been lowered between 0.5 and $1.5 \mathrm{mg} \mathrm{N} . \mathrm{L}^{-1}$ since the implementation of the new wastewater treatment. Even if ammonium concentrations remain above the EU-WFD's good quality criterion of $0.5 \mathrm{mg} \mathrm{NH} \mathrm{NH}_{4}^{+} . \mathrm{L}^{-1}$ (DRIEE, 2007), since 2007 the estuarine zone is much less ammonium-contaminated than it was before.

Nitrate concentrations, which increased progressively downstream of Paris following the nitrification of ammonium, are now showing a slight increase directly downstream of the SAV WWTP followed by a stable level along the profile (Fig. 3). The Eure River tributary, with a higher nitrate concentration, is responsible for a slight increase between 202 and $250 \mathrm{~km}$.

Today, elevated nitrite concentrations are perceived as the most serious water-quality problem in the Lower Seine River sector beginning from $76 \mathrm{~km}$ at Poissy to $229 \mathrm{~km}$ at Oissel, with $\mathrm{NO}_{2}^{-}$concentrations above the good EU-WFD quality criteria of $0.3 \mathrm{mg} \mathrm{NO} \mathrm{NO}_{2}^{-} \cdot \mathrm{L}^{-1}$. As an 
2001-2003
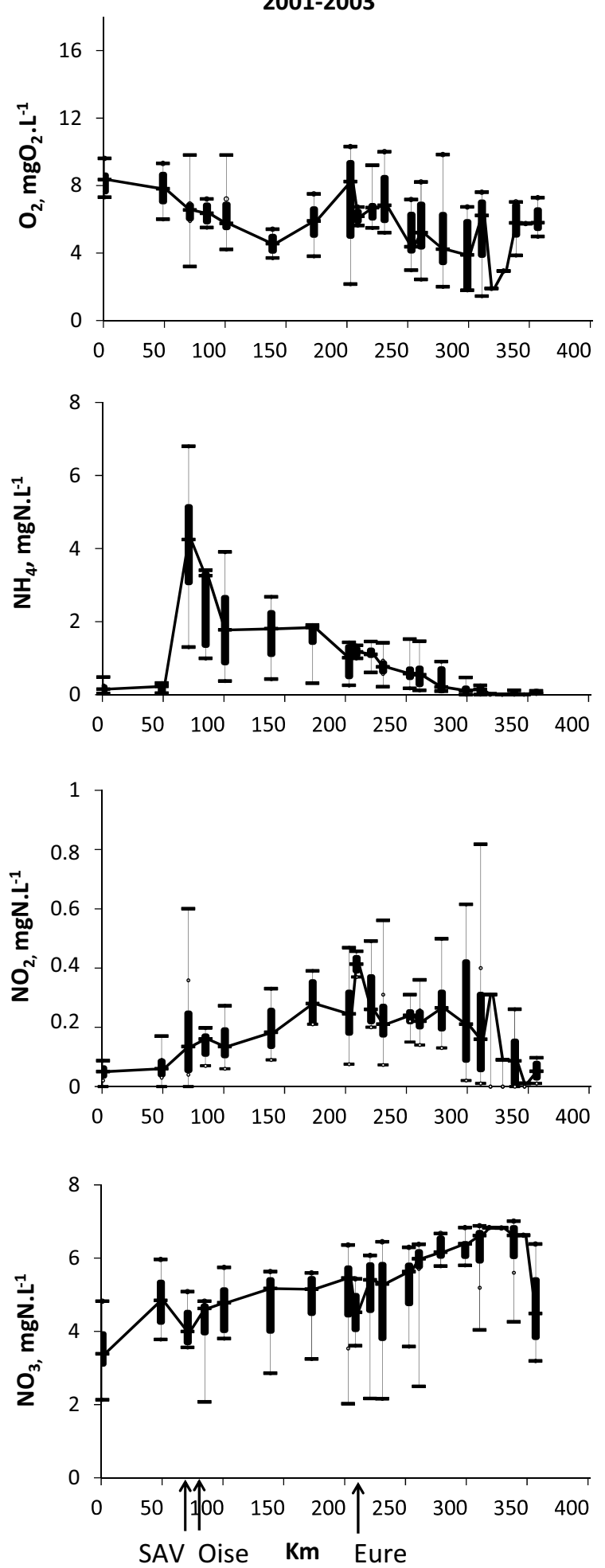

2011-2014
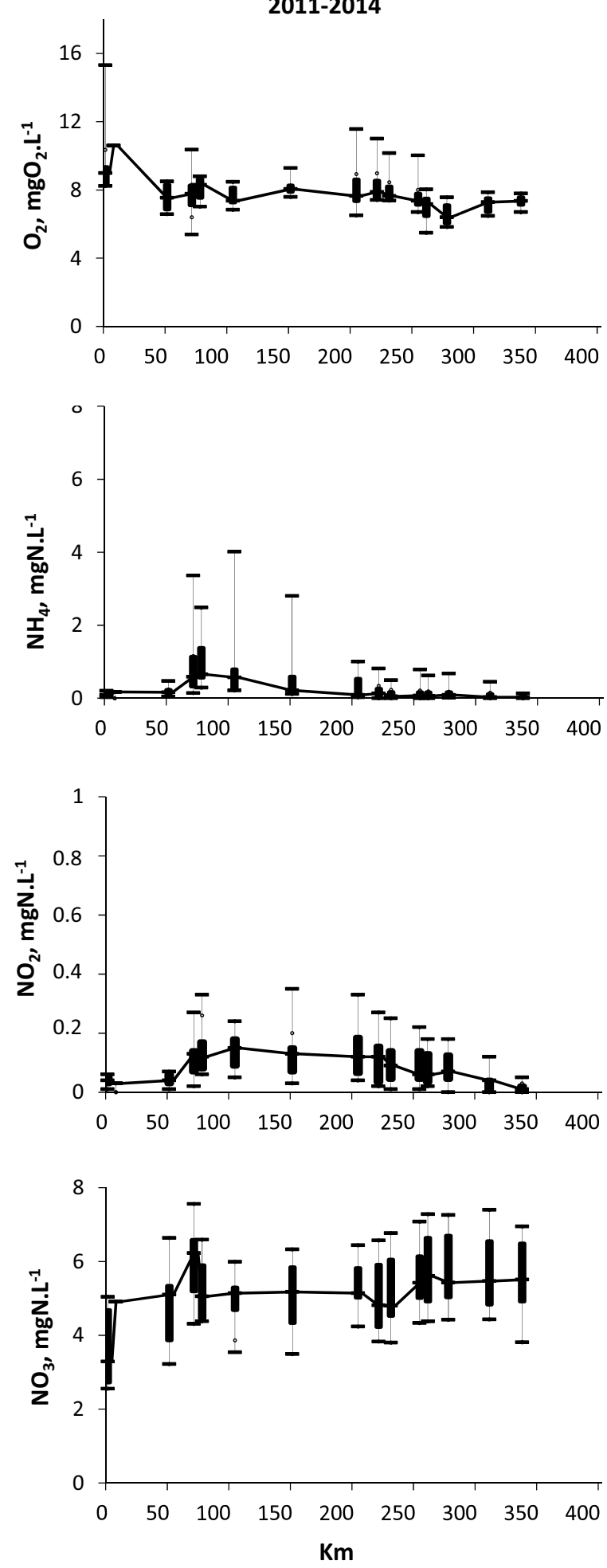

Fig. 4. Longitudinal variations of oxygen, ammonium, nitrite and nitrate concentrations along the lower Seine River and estuary. Comparison of the 2001-2003 and 2011-2014 periods from upstream of Paris, at the confluence with the Marne River (0 km) to Tancarville downstream of the estuary $(350 \mathrm{~km})$. SAV WWTP is at $65 \mathrm{~km}$ and Poses the limit of the estuary at $202 \mathrm{~km}$.

intermediate product in nitrification and denitrification, nitrite is a good indicator of the equilibrium between these two processes. The measurements show that the sectors affected by high nitrite concentrations are much less extended today than they were 10 years ago for low spring and summer discharges (Fig. 4). At that time, levels of $\mathrm{NO}_{2}^{-}$well above $0.09 \mathrm{mg} \mathrm{N}-\mathrm{NO}_{2}^{-} \cdot \mathrm{L}^{-1}$ were frequently observed in the lower Seine River and its fluvial estuarine 

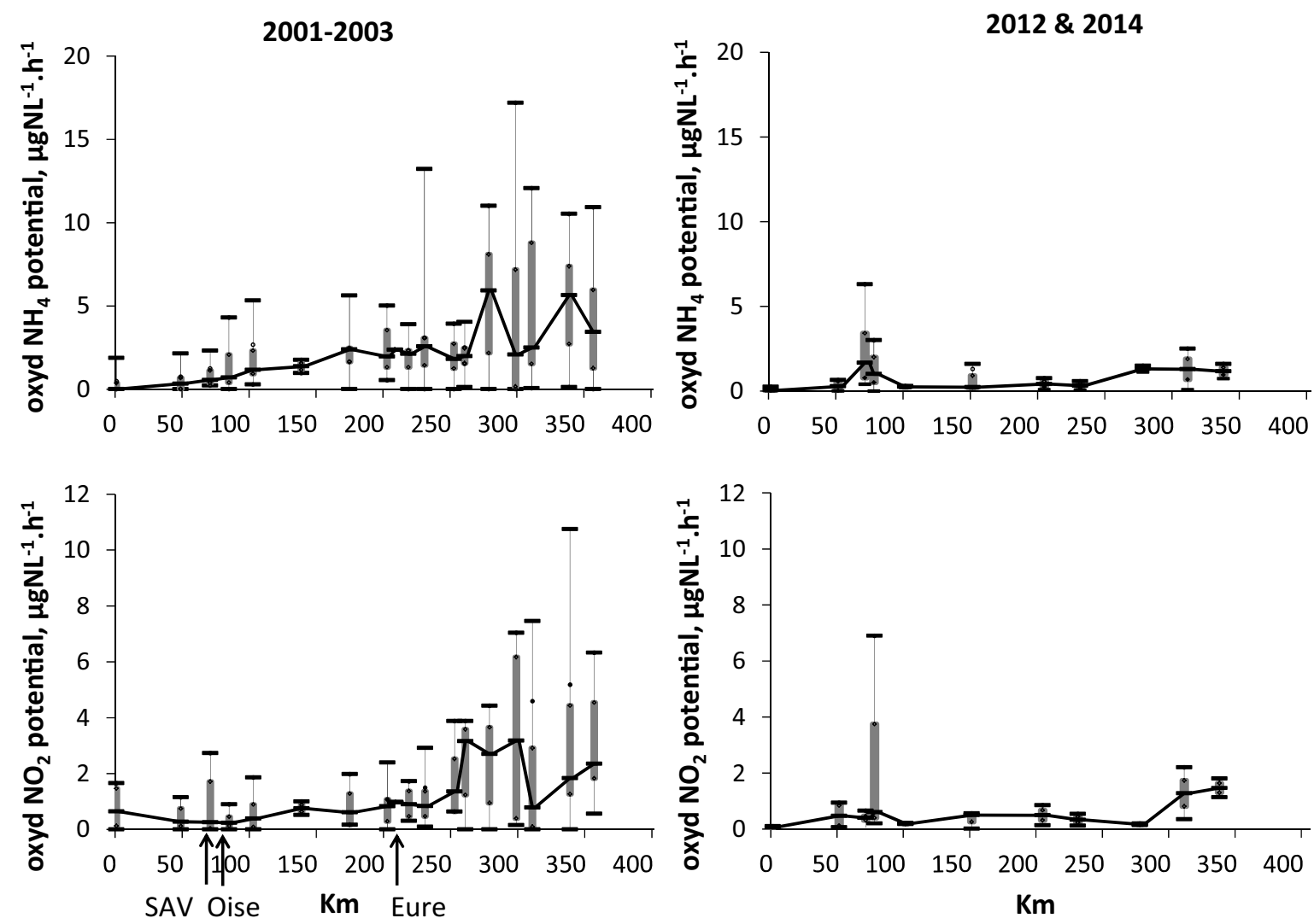

Fig. 5. Longitudinal variations of oxidizing ammonium and nitrite potentials along the lower Seine River in 2001-2003 and 2012 and 2014.

zone from $101 \mathrm{~km}$ at Porcheville to $337 \mathrm{~km}$ at Tancarville, as a result of ammonium oxidation not immediately balanced by nitrite oxidation. Nowadays, the currently observed high nitrite concentrations originates from the direct impact of the SAV WWTP effluents, characterized by higher nitrite concentrations than before 2007 .

In 2002-2003, the potential ammonium- and nitriteoxidizing activities showed only a slight increase downstream of the treatment plant, followed by a gradual increase down to the estuarine zone, reaching a peak in the area of its maximum turbidity. The presence of high concentrations of ammonium and nitrite in the water clearly stimulated the growth of the nitrifying microorganisms (Fig. 5). In the recent period, the profiles carried out in April, June, and August 2012 and May 2014 show a different general trend that begins with a peak of nitrifying activity immediately downstream of the SAV WWTP and then a decrease in these activities in the downstream sector. Only in the maximum turbidity zone is a slight increase observed, as a result of the attachment of microbial biomass onto particulate material and the concentration of this material. The overall pattern observed in the recent period is consistent with a large input of organisms with the effluents of the WWTP, followed by a gradual disappearance of the organisms that have limited growth possibly due to a lack of substrate availability.

\section{Interruption of SAV nitrogen treatment}

The profiles in May 2011 and September 2013 showed two situations when nitrification treatment at the SAV WWTP was interrupted for maintenance purposes (Fig. 6). During these periods the effluents from the SAV treatment plant contained high concentrations of ammonium, 30.6 and $18.7 \mathrm{mg} \mathrm{N} . \mathrm{L}^{-1}$, respectively, i.e., about 20 times more than observed in the other profiles. Logically, the corresponding longitudinal profiles of nitrogen forms and nitrifying organisms reflect the return of the conditions to those observed before the implementation of the nitrification treatment. Ammonium concentrations downstream of SAV were up to $4 \mathrm{mg} \mathrm{N} . \mathrm{L}^{-1}$ at Porcheville $101 \mathrm{~km}$ and elevated nitrite concentrations extended to the downstream estuarine zone until they disappeared at Tancarville $337 \mathrm{~km}$ (Fig. 6). During the September 2013 campaign, a peak in the ammonium oxidation activity reaching $15.3 \mu \mathrm{g} \mathrm{N} . \mathrm{L}^{-1} \cdot \mathrm{h}^{-1}$ was observed in the estuarine zone at Caudebec $310 \mathrm{~km}$ (Fig. 6). The high ammonium concentrations clearly allowed the growth of nitrifying microorganisms in the lower Seine River and led to a higher nitrite concentration reaching $0.36 \mathrm{mg} \mathrm{N}-\mathrm{NO}_{2} \cdot \mathrm{L}^{-1}$ at Vernon $150 \mathrm{~km}$, beyond levels achieved in today's normal WWTP functioning conditions. The dynamics of nitrogen forms and nitrifying organisms resemble those observed between 2001 and 

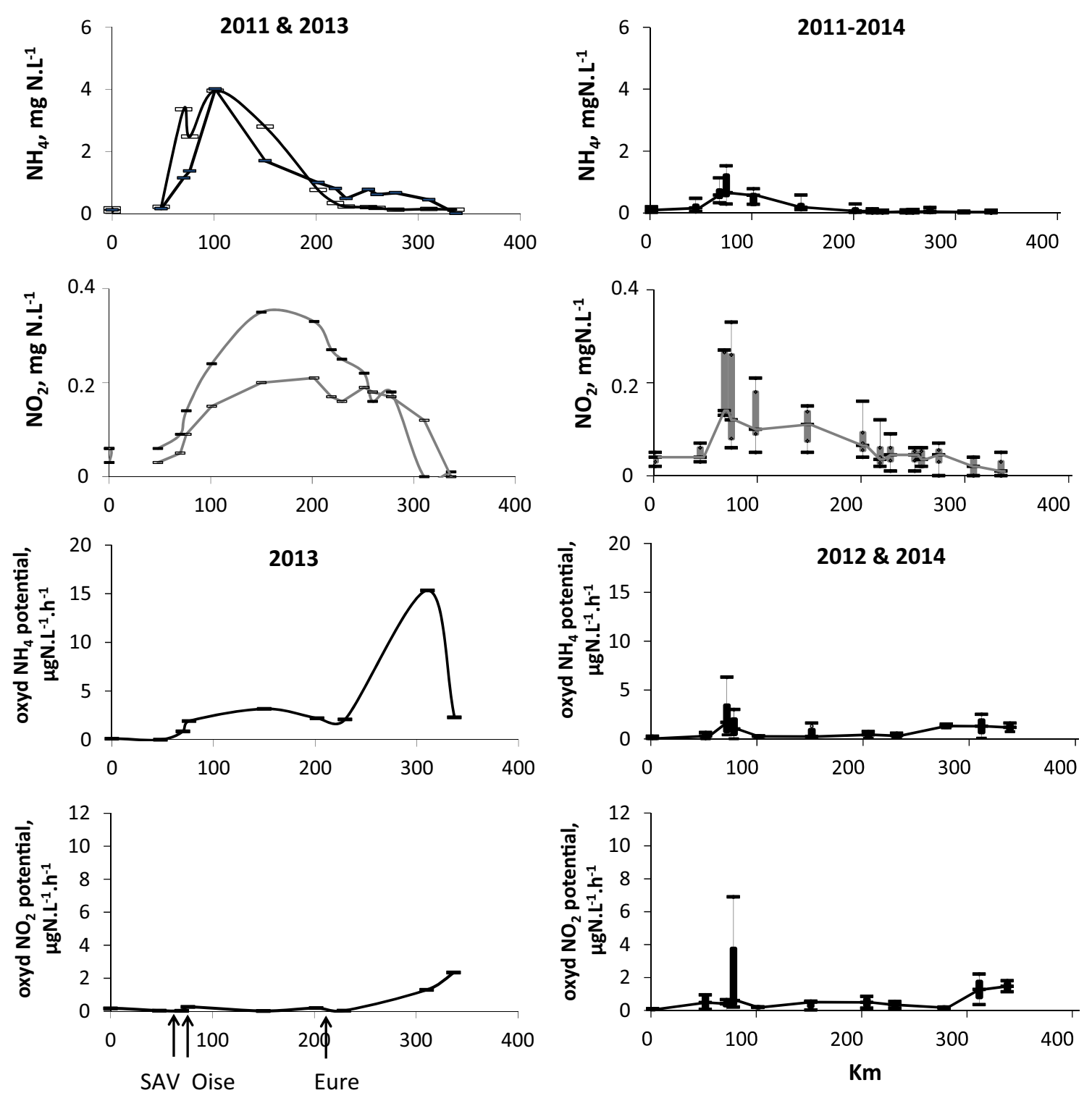

Fig. 6. Along the Seine River continuum, comparison of ammonium and nitrite concentrations between two WWTP maintenance periods (May 2011 and September 2013) (left panel) and five campaigns carried out in 2011-2014 during normal WWTP operation and comparison of potential ammonium and nitrite oxidation activities during WWTP maintenance in September 2013 (left panel) and normal operation in 2012 and 2014.

2003 before the introduction of nitrogen treatment in the SAV plant (Figs. 3 and 5).

\section{Discussion}

\section{Modeling nitrogen and nitrifying organism dynamics}

In order to analyze the coherence of the results, a simplified biogeochemical model was constructed for permanent flow conditions to simulate the variation of $\mathrm{O}_{2}$ concentrations, organic matter $(\mathrm{OM}), \mathrm{NH}_{4}^{+}, \mathrm{NO}_{2}^{-}$and $\mathrm{NO}_{3}^{-}$, bacterial heterotrophic biomass (BAC), ammonium-oxidizing biomass (NIT) and nitrite-oxidizing biomass (NAT) during the downstream transfer of a Seine water body from upstream of Paris to the estuary. This water mass is subject to the inputs of organic matter, nitrogen nutrients and microorganisms from the SAV plant as estimated above, and the dynamics of nitrogen species and nitrifying microorganisms is represented according to the formalism developed for the RIVE model based on studies of cultivated bacterial populations and experiments with natural communities (Billen, 1991; Billen et al., 1994; Brion and Billen, 1998; Garnier et al., 2002, 2005, 2007; Cébron et al., 2004). Table 3 summarizes the kinetic representation used for the model and the values of the corresponding parameters. Processes related to algal activity and benthos are not included in this simplified model. Hydraulic processes are represented as a simple plug-flow in a fairway with a constant wetted cross-section 
Table 3. Formalism of oxygen, organic matter, inorganic nitrogen species and nitrifying bacteria dynamics in the Seine River with associated parameter values.

$\mathrm{dO}_{2} / \mathrm{dt}=$ krea $\left(\mathrm{O}_{2} \mathrm{sat}-\mathrm{O}_{2}\right)-\mathrm{a}_{\text {het }}$. Acthet $-\mathrm{a}_{\text {nit }}$ Nitros $-\mathrm{a}_{\text {nat }}$ Nitrat

$\mathrm{dOM} / \mathrm{dt}=-$ Acthet $+\mathrm{kd}_{\mathrm{bac}} \mathrm{BAC}$

$\mathrm{dBAC} / \mathrm{dt}=\mathrm{Y}_{\mathrm{bac}}$ Acthet $-\mathrm{kd}_{\mathrm{bac}} \mathrm{BAC}$

$\mathrm{dNH}_{4} / \mathrm{dt}=-$ Nitros $+\mathrm{b}$ Acthet

$\mathrm{dNO}_{2} / \mathrm{dt}=$ Nitros - Nitrat

$\mathrm{dNO}_{3} / \mathrm{dt}=$ Nitrat

$\mathrm{dNIT} / \mathrm{dt}=\mathrm{Y}_{\text {nit }}$ Nitros $-\mathrm{kd}_{\text {nit }} \mathrm{NIT}$

$\mathrm{dNAT} / \mathrm{dt}=\mathrm{Y}_{\text {nat }}$ Nitrat $-\mathrm{kd}_{\text {nat }} \mathrm{NAT}$

with Acthet $=$ Het $_{\max } \mathrm{OM} /\left(\mathrm{OM}+\mathrm{K}_{\mathrm{OM}}\right)$

Nitros $=\mathrm{Nit}_{\max } \mathrm{NH}_{4} /\left(\mathrm{NH}_{4}+\mathrm{K}_{\mathrm{NH} 4}\right) \mathrm{O}_{2} /\left(\mathrm{O}_{2}+\mathrm{Knit}_{\mathrm{O} 2}\right)$

$\mathrm{Nitrat}=\mathrm{Nat}_{\max } \mathrm{NO}_{2} /\left(\mathrm{NO}_{2}+\mathrm{K}_{\mathrm{NO} 2}\right) \mathrm{O}_{2} /\left(\mathrm{O}_{2}+\mathrm{Knat}_{\mathrm{O} 2}\right)$

\begin{tabular}{|c|c|c|c|c|c|}
\hline$\underline{\text { Parameter }}$ & & $\begin{array}{c}\text { BAC } \\
\text { (heterotr. Bacterial } \\
\text { biomass) }\end{array}$ & $\begin{array}{c}\text { NIT } \\
\text { (ammonium-oxidizing } \\
\text { biomass) }\end{array}$ & $\begin{array}{c}\text { NAT } \\
\text { (nitrite-oxidizing } \\
\text { biomass) }\end{array}$ & Unit \\
\hline$\overline{H e t}_{\max }$ & Max sp. rate of OM degradation & 0.6 & & & $\mathrm{~h}^{-1}$ \\
\hline $\mathrm{Nit}_{\max }, \mathrm{Nat}_{\max }$ & Max. sp. activity & & 0.95 & 3 & mgN.mg C ${ }^{-1} \cdot h^{-1}$ \\
\hline$Y_{\text {het }}$ & Growth yield & 0.4 & & & $\mathrm{MgC} \mathrm{mgC}^{-1}$ \\
\hline$Y_{\text {nit }}, Y_{\text {nat }}$ & Growth yield & & 0.07 & 0.02 & $\mathrm{MgC} \cdot \mathrm{mgN}^{-1}$ \\
\hline $\mathrm{K}_{\mathrm{OM}}$ & Half saturation constant & 0.2 & & & Mg C.L $\mathrm{L}^{-1}$ \\
\hline$K_{\mathrm{N}}$ & Half saturation constant & & 1 & 0.03 & MgN.L ${ }^{-1}$ \\
\hline Knit ${ }_{\mathrm{O} 2} /$ nat $_{\mathrm{O} 2}$ & Half saturation constant & & 0.5 & 1.2 & $\mathrm{MgO}_{2} \cdot \mathrm{L}^{-1}$ \\
\hline$k_{\mathrm{d}}$ & Mortality constant & 0.07 & 0.005 & 0.005 & $\mathrm{~h}^{-1}$ \\
\hline Ahet & Stoechiometric constant & 2.67 & & & $\mathrm{mgO}_{2} \cdot \mathrm{mg} \mathrm{C}^{-1}$ \\
\hline$a_{\text {nit }}, a_{\text {nat }}$ & Stoechiometric constant & & 6.86 & 2.29 & $\mathrm{mgO}_{2} \cdot \mathrm{mgN}^{-1}$ \\
\hline$b$ & Stoechiometric constant & 0.14 & & & mgN.mg C -1 \\
\hline$k_{\text {rea }}$ & Reaeration constant & 0.02 & & &.$h^{-1}$ \\
\hline
\end{tabular}

Nitros/Nitrat: oxidizing ammonium/nitrite activity, Acthet: heterotrophic activity.

(400 and $600 \mathrm{~m}^{2}$, respectively, for upstream and downstream of the confluence with the Oise River) and therefore only determined by the Seine flow at the Paris intra muros station $\left(150 \mathrm{~m}^{3} \cdot \mathrm{s}^{-1}\right)$ and the Oise flow at the Conflans station $\left(100 \mathrm{~m}^{3} \cdot \mathrm{s}^{-1}\right)$. The navigation dams are taken into account to calculate the re-aeration. The model is implemented in a simple Excel sheet.

This simple model correctly simulates the processes described above in the lower Seine River (Fig. 7). Given the value of the inputs of nutrients and microorganisms released by the SAV plant, it calculates the dynamics of organic carbon, ammonium, nitrite, nitrate, oxygen and nitrifying organisms along the downstream trajectory of the water mass, starting upstream of the Paris agglomeration.

With inputs of organic carbon, ammonium, nitrite and nitrate from the SAV plant prior to the implementation of nitrogen treatment, evaluated at 30 tons orgC.day ${ }^{-1}$, 8 tons $\mathrm{C}$ of heterotrophic biomass, 60 tons $\mathrm{N}_{-} \mathrm{NH}_{4}^{+}$.day ${ }^{-1}$, 0 ton $\mathrm{N}-\mathrm{NO}_{3}^{-} \cdot$ day $^{-1}, 1$ ton $\mathrm{N}-\mathrm{NO}_{2}^{-}$.day ${ }^{-1}$, respectively (along with minor contributions from the Clichy $30 \mathrm{~km}$ and Rouen $247 \mathrm{~km}$ wastewater releases), and considering an average release of $20 \mathrm{~kg} \mathrm{C} \cdot \mathrm{day}^{-1}$ of ammoniumoxidizing biomass and $4 \mathrm{~kg} \mathrm{C} \cdot \mathrm{day}^{-1}$ of nitrite-oxidizing biomass (Table 3), the model reproduces the main trends of oxygen concentrations and nutrients observed in the 2002-2003 period. A significant oxygen deficit accompanied by a high concentration of nitrite is accurately simulated in the estuarine zone, following the growth of nitrifying organisms stimulated by high ammonium concentrations (Fig. 7).

With the releases corresponding to the post-2007 period (i.e., 15 tons orgC.day ${ }^{-1}$, about 1 ton C.day ${ }^{-1}$ of heterotrophic biomass, 10 tons $\mathrm{N}-\mathrm{NH}_{4}^{+} \cdot$ day $^{-1}$, 30 tons $\mathrm{N}-\mathrm{NO}_{3}^{-}$. day ${ }^{-1}, 5$ tons $\mathrm{N}-\mathrm{NO}_{2}^{-}$. day ${ }^{-1}, 20 \mathrm{~kg} \mathrm{C}$. day $^{-1}$ of ammonium-oxidizing biomass and $7 \mathrm{kgC}$ day $^{-1}$ of nitriteoxidizing biomass), the simulation (Fig. 7) shows different nitrifying dynamics, close to the observations conducted during the 2012-2014 campaigns. The oxygen deficit in the estuarine zone is no longer present. The growth of nitrifying microorganisms is limited by the very low substrate concentrations in the environment. The nitrite supply by the SAV plant is metabolized progressively downstream from the treatment plant outfall.

The good agreement with the simulations and the observations for both periods, taking into account their respective constraints (i.e., inputs), indicate a good representation of the kinetics of the processes and a correct evaluation of the associated parameters.

Pauer and Auer (2000) developed the view that nitrification in rivers is mainly a sediment-based process and, as such, should be modeled by zero-order kinetics rather than by a first-order reaction driven by water column ammonium concentration. The analysis of nitrification in large European rivers and estuaries contaminated by urban pollution like the Seine River contradicts this point of view and shows that water column nitrification is affected by the activity of planktonic or sestonic 

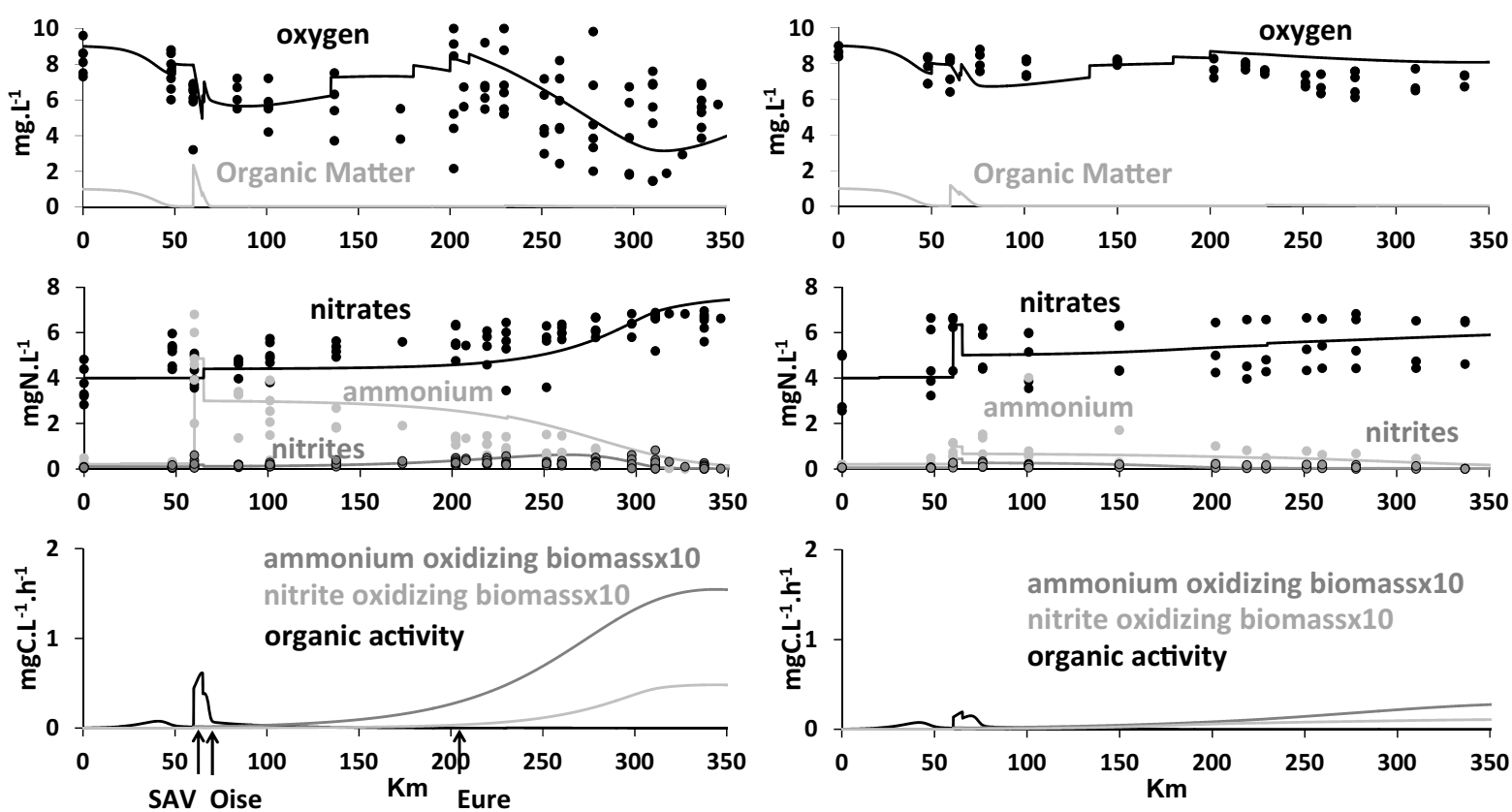

Fig. 7. Simulation of oxygen, organic matter, ammonium, nitrite, nitrate, ammonium and nitrite-oxidizing biomass and heterotrophic (organic) activity for the 2001-2003 period (left panel) and 2011-2013 period (right panel) in the Seine River continuum from Paris, at the confluence with the Marne River $(0 \mathrm{~km})$ to Tancarville, downstream of the estuary $(337 \mathrm{~km})$.

communities of microorganisms largely originating from wastewater releases themselves. However, simple firstorder kinetics would be unable to reproduce the observed dynamics of inorganic nitrogen and oxygen concentrations downstream from wastewater release. The present results on the Seine River clearly show that taking into account the development of microbial populations of nitrifying organisms is essential to explain the observed spatial and temporal pattern of nitrification, with a delay of several days (more than $100 \mathrm{~km}$ along the Seine profile) before the ammonium begins to be oxidized.

\section{Long-term observations of water quality for acknowledging major changes}

The data presented above, obtained at approximately 10-year intervals, before and after the implementation of nitrification treatment of the Parisian wastewater in the SAV plant, show the considerable changes that affected the nitrification dynamics in the system. Our measurements indicate strong modifications in the fluxes of nitrogen forms and microorganisms released by the WWTP, with much less ammonium, more nitrite and more nitrifying microorganisms presently released compared with the previous situation. As a consequence, ammonium-oxidizing microorganisms, although released in higher amounts by the effluents, are no longer very active in the river due to a lack of substrate in sufficiently high concentrations (less than their Ks value of about $1 \mathrm{mg}$ $\mathrm{N}-\mathrm{NH}_{4}^{+} \cdot \mathrm{L}^{-1}$ ). This results in the disappearance of the oxygen deficit area that previously occurred in the upstream estuarine zone.
For the same reason, much less nitrite is produced by ammonium oxidation and the major source of nitrite contamination is the direct release with treated effluents of the SAV plant, which might be caused by an imbalance between ammonium and nitrite oxidation rates in the wastewater treatment process and is only slowly metabolized in the river by nitrite-oxidizing microorganisms. The area affected by nitrite contamination therefore moved from the upstream estuary to the Seine River stretch immediately downstream of the SAV plant. In spite of this nitrite contamination problem, the water quality of the whole Seine River downstream from Paris has significantly improved following the implementation of the new nitrogen treatment.

Nevertheless, when this treatment is interrupted, as observed on two occasions in our sampling program, a return to the conditions prior to 2007 is observed, showing the complete reversibility of the changes described.

Besides the changes in the brought substrates, all these results illustrate and confirm the role of the SAV WWTP as a seeding source of nitrifying bacteria for the Seine River (Servais et al., 1999; Brion et al., 2000; Cébron et al., 2003; Garnier et al., 2006b, 2007). The release of these microorganisms is even more significant today (a majority in Nitrospira, T. Cazier, personal communication, 2015) than in the early $2000 \mathrm{~s}$, but the strong reduction of ammonium contamination would prevent the development of these microorganisms in the river.

The long-term trajectory of water-quality improvement of the lower Seine River over the last 40 years is summarized in Figure 8, where the average nitrification rate in the Seine River stretch downstream of Paris is plotted against the maximum ammonium concentration 


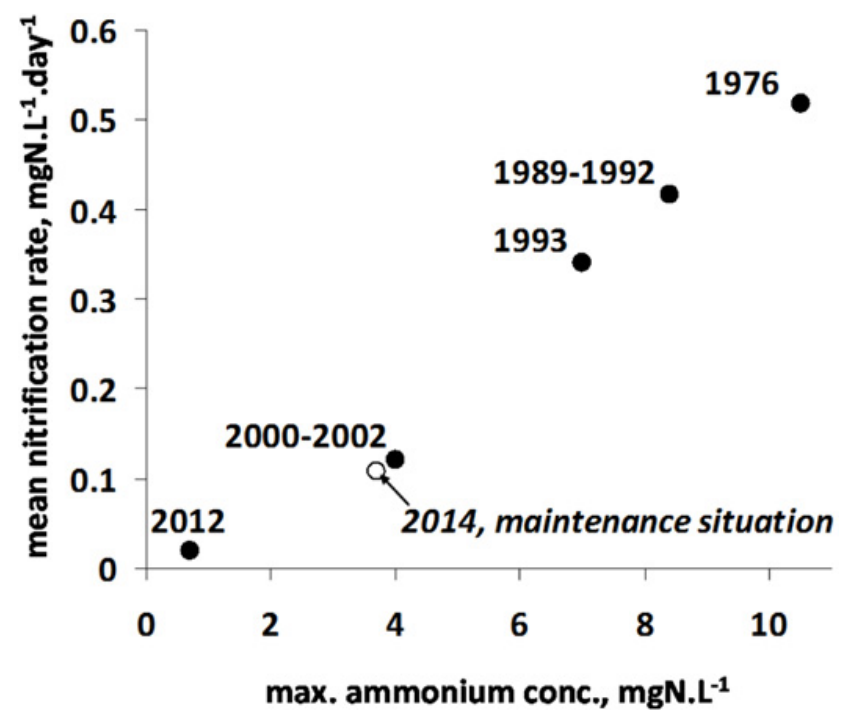

Fig. 8. Observed average nitrification rate in the lower Seine River (70-300 km) plotted against the maximum ammonium concentration downstream of Paris since the 1970s. Data from Brion and Billen (2000), Garnier et al. (2006b) and this study. Nitrification rate is defined here as the sum of ammonium and nitrite oxidation rates either measured together or separately. Maximum ammonium concentration is taken here as an indicator of the ammonium input by WWTP.

recorded by low flow conditions, combining the observations reported in this paper and those of (Brion and Billen, 2000) and Garnier et al. (2006a).

The observations in Figure 8 for the Seine are in agreement with several other studies although we did not found the quantitative data for including them in the figure. For example, He et al. (2014) attested that controlling sewage discharge and local urban runoff is very important in order to improve water quality in the Pearl River estuary in China. They indeed, showed that $\mathrm{NH}_{4}^{+}$derived from sewage loadings dominates the nitrification process and the associated oxygen consumption. McMellor and Underwood (2014) also demonstrated that the reduction in nutrient concentrations in the Colne Estuary (England) between 1980 and 2010 and the abatement in ammonium inputs were due to active interventions in wastewater treatment industry in the catchments. Similar changes have been reported in longterm studies from the Scheldt estuary (Belgium and Netherlands) from the mid-1970s (Soetaert et al., 2006), in the Marsdiep, Helgoland, Odense Fjord, Gulf of Riga systems (Duarte et al., 2009), in Nervión in the Basque region of Spain (Borja et al., 2010), and in some US estuaries (Alexander and Smith, 2006; Carstensen et al., 2011).

As a whole, once ammonium contamination has been considerably reduced with the new treatment lines of the WWTPs, encouraged by European and national directives, nitrite levels above the recommended values still contribute to downgrade the water quality. However, the nitrite concentrations previously produced in the river water column were higher than the present ones, mostly originating from the WWTP effluents. Even though their progressive elimination is observed in the lower Seine, nitrite remains persistent along $200 \mathrm{~km}$ downstream before being either completely metabolized by nitrite-oxidizing microbes or diluted by sea water in the estuary.

Acknowledgements. This study was undertaken within the framework of the R2DS Ile-de-France and the PIREN-Seine research program. The authors are part of the Ile-de-France Federation for Research on the Environment (FIRE FR3020 CNRS \& UPMC). We are grateful to the SIAAP (Public Sewage Company of the greater Paris Area) and to AESN (SeineNormandy Water Agency) for the data they supplied.

\section{References}

Admiraal W. and Botermans Y.J., 1989. Comparison of nitrification rates in three branches of the lower river Rhine. Biogeochemistry, 8, 135-151.

Alexander R.B. and Smith R.A., 2006. Trends in the nutrient enrichment of U.S. rivers during the late 20th century and their relation to changes in probable stream trophic conditions. Limnol. Oceanogr., 51(1), 639-654.

Billen G., 1975. Nitrification in the Scheldt estuary (Belgium and Netherlands). Estuar. Coast. Mar. Sci., 3, 79-89.

Billen G., 1991. Protein Degradation in Aquatic Environments. Microbial Enzymes in Aquatic Environments, Springer, New York, 123-143.

Billen G., Garnier J. and Hanset P., 1994. Modelling Phytoplankton Development in Whole Drainage Networks: the RIVERSTRAHLER Model Applied to the Seine River System. Phytoplankton in Turbid Environments: Rivers and Shallow Lakes, Springer, Netherlands, 119-137.

Billen G., Garnier J., Ficht A. and Cun C., 2001. Modelling the response of water quality in the Seine Estuary to human activity in its watershed over the last 50 years. Estuaries, 24, 977-993.

Borja Á., Elliott M., Carstensen J., Heiskanen A.S. and van de Bund W., 2010. Marine management-towards an integrated implementation of the European Marine Strategy Framework and the water framework directives. Mar. Pollut. Bull., 60, 2175-2186.

Bouraoui F. and Grizzetti B., 2011. Long term change of nutrient concentrations of rivers discharging in European seas. Sci. Total Environ., 409(23), 4899-4916.

Brion N. and Billen G., 1998. Une réévaluation de la méthode d'incorporation de $\mathrm{H} 14 \mathrm{CO} 3$ - pour mesurer la nitrification autotrophe et son application pour estimer des biomasses de bactéries nitrifiantes. Revue Sciences de l'Eau, 11, 283-302.

Brion N. and Billen G., 2000. Wastewater as a source of nitrifying bacteria in river systems: the case of the River Seine downstream from Paris. Water Res., 34, 3213-3221.

Brion N., Billen G., Guezennec L. and Ficht A., 2000. Distribution of nitrifying activity in the Seine River (France) from Paris to the estuary. Estuaries, 23, 669-682.

Carstensen J., Sánchez-Camacho M., Duarte C.M., KrauseJensen D. and Marba N., 2011. Connecting the dots: 
responses of coastal ecosystems to changing nutrient concentrations. Environ. Sci. Technol., 45(21), 9122-9132.

Cébron A., 2004. Nitrification, Bactéries nitrifiantes et Emission de N2O : La Seine en aval de Paris. Thèse de doctorat, Paris 6 : Université Paris VI - Pierre et Marie Curie.

Cébron A. and Garnier J., 2005. Nitrobacter and Nitrospira genera as representatives of nitrite-oxidizing bacteria: detection, quantification and growth along the lower Seine River (France). Water Res., 39, 4979-4992.

Cébron A., Berthe T. and Garnier J., 2003. Nitrification and nitrifying bacteria in the lower seine river and estuary (France). Appl. Environ. Microbiol., 69, 7091-7100.

Cébron A., Coci M., Garnier J. and Lannbroek H.J., 2004. Denaturing gradient gel electrophoretic analysis of ammonia-oxidizing bacterial community structure in the lower seine river: impact of Paris Wastewater effluents. Appl. Environ. Microbiol., 70, 6726-6737.

Cébron A., Garnier J. and Billen G., 2005. Nitrous oxide production and nitrification kinetics by natural bacterial communities naturally present in river water (the lower Seine, France). Aquat. Microb. Ecol., 41, 25-38.

Chesterikoff A., Garban B., Billen G. and Poulin M., 1992. Inorganic nitrogen dynamics in the River Seine downstream from Paris (France). Biogeochemistry, 17, 147-164.

Cooper A.B., 1984. Activities of benthic nitrifiers in streams and their role in oxygen consumption. Microb. Ecol., 10, 317-334.

Curtis E.J.C., Durrant K. and Harman M.M.I., 1975. Nirification in rivers in the Trent Basin. Water Res., 9, 255-268.

de Bie M.J., Starink M., Boschker H.T., Peene J.J. and Laanbroek H.J., 2002. Nitrification in the Schelde estuary: methodological aspects and factors influencing its activity. FEMS Microbiol. Ecol., 42, 99-107.

de Wilde H.P.J. and de Bie M.J.M., 2000. Nitrous oxide in the Schelde estuary: productionbynitrification and emission to the atmosphere. Mar. Chem., 69, 203-216.

DRIEE, 2007. La qualité des cours d'eau en Ile de France: évolution de la qualité des eaux superficielles sur la période 2001-2005. Direction régionale de l'environnement Ile de France.

Duarte C.M., Conley D.J., Carstensen J. and Sánchez-Camacho M., 2009. Return to Neverland: shifting baselines affect eutrophication restoration targets. Estuar. Coasts, 32, 29-36.

EU-WFD (Water Framework Directive), 2000. OJ L 327/1, 22.12, pp. 1-72.

Garnier J., Servais P., Billen G., Akopian M. and Brion N., 2001. The oxygen budget in the Seine estuary: balance between photosynthesis and degradation of organic matter. Estuaries, 24(6), 964-977.

Garnier J., Billen G., Hannon E., Fonbonne S., Videnina Y. and Soulie M., 2002. Modelling the transfer and retention of nutrients in the drainage network of the Danube river. Estuar. Coast. Shelf Sci., 54, 285-308.

Garnier J., Némery J., Billen G. and Théry S., 2005. Nutrient dynamics and control of eutrophication in the Marne River system: modelling the role of exchangeable phosphorus. Journal of Hydrology, 304(1), 397-412.

Garnier J., Cébron A., Tallec G., Billen G., Sebilo M. and Martinez A., 2006a. Nitrogen behaviour and nitrous oxide emission in the tidal Seine River estuary (France) as influenced by human activities in the upstream watershed. Biogeochemistry, 77, 305-326.
Garnier J., Laroche L. and Pinault S., 2006b. Determining the domestic specific loads of two wastewater plants of the Paris conurbation (France) with contrasted treatments: a step for exploring the effects of the application of the European Directive. Water Res., 40, 3257-3266.

Garnier J., Billen G. and Cébron A., 2007. Modelling nitrogen transformations in the lower Seine river and estuary (France): impact of wastewater release on oxygenation and $\mathrm{N}_{2} \mathrm{O}$ emission. Hydrobiologia, 588, 291-302.

Garnier J., Billen G., Even S., Etcheber H. and Servais P., 2008. Organic matter dynamics and budgets in the turbidity maximum zone of the Seine Estuary (France). Estuar. Coast. Shelf Sci., 77, 150-162.

Garnier J., Brion N., Callens J., Passy P., Deligne C., Billen G., Servais P. and Billen C., 2013. Modelling historical changes in nutrient delivery and water quality of the Zenne river (1790s-2010): the role of land use, waterscape and urban wastewater management. J. Mar. Syst., 128, 62-76. http:// dx.doi.org/10.1016/j.jmarsys.2012.04.001.

He B., Dai M., Zhai W., Guo X. and Wang L., 2014. Hypoxia in the upper reaches of the Pearl River Estuary and its maintenance mechanisms: a synthesis based on multiple year observations during 2000-2008. Mar. Chem., 167, 13-24.

Helder W. and De Vries R.T.P., 1983. Estuarine nitrite maxima and nitrifying bacteria (Ems-Dollard estuary). Neth. J. Sea Res., 1, 1-18.

Jones M.N., 1984. Nitrate reduction by shaking with cadmium: alternative to cadmium columns. Water Res., 18, 643-646.

McMellor S. and Underwood G.J.C., 2014. Water policy effectiveness: 30 years of change in the hypernutrified Colne estuary, England. Mar. Pollut. Bull., 81, 200-209.

Müller D. and Kirchesch V., 1985. On nitrification in the River Rhine. Verh. Int. Ver. Limnol, 22, 2754-2760.

Owens N.J., 1986. Estuarine nitrification: a naturally occurring fluidized bed reaction? Estuar. Coast. Shelf Sci., $22,31-44$.

Passy P., Gypens N., Billen G., Garnier J., Lancelot C., Thieu V., Rousseau V. and Callens J., 2013. A Model reconstruction of riverine nutrient fluxes and eutrophication in the Belgian Coastal Zone since 1984. J. Mar. Syst., 128, 106-122. http://dx.doi.org/10.1016/ j.jmarsys.2013.05.005.

Pauer J.J. and Auer M.T., 2000. Nitrification in the water column and sediment of a hypereutrophic lake and adjoining river system. Water Res., 34, 1247-1254.

Prosser J.I., 1989. Autotrophic nitrification in bacteria. $A d v$. Microb. Physiol., 20, 125-192.

Servais P., Garnier J., Demarteau N., Brion N. and Billen G., 1999. Supply of organic matter and bacteria to aquatic ecosystems through waste water effluents. Water Res., 33, $3521-3531$.

Slawyk G. and MacIssac J.J., 1972. Comparison of two automated ammonium methods in a region of coastal upwelling. Deep Sea Res. Oceanogr. Abstr. Elsevier, 19, 521-524.

Soetaert K., Middelburg J.J., Heip C., Meire P., Van Damme S. and Maris T., 2006. Long-term change in dissolved inorganic nutrients in the heterotrophic Scheldt estuary (Belgium, the Netherlands). Limnol. Oceanogr., 51(1part2), 409-423. 
Somville M., Billen G. and Smitz J., 1982. An ecophysiological model of nitrification in the Scheldt estuary. Math. Model., 3, 523-533.

Tusseau-Vuillemin M.H., Garnier J., Servais P. and Laroche L., 2002. Charges domestiques spécifiques et rejets de stations d'épuration. Rapport d'avancement Piren-Seine: Dynamique de la matière organique et des microorganismes dans les systèmes urbains, Paris.

Xia X.H., Yang Z.F., Huang G.H., Zhang X.Q., Yu H. and Rong X., 2004. Nitrification in natural waters with high suspended-solid content - a study for the Yellow River. Chemosphere, 57, 1017-1029. 